\title{
The value resonance of Lu Xun's Zawen and college ideological and political work \\ Wenping Ma ${ }^{1, \mathrm{a}}{ }^{*}$, Yanjun Dai ${ }^{2, \mathrm{~b}}$, Fenghuang Jin ${ }^{3, \mathrm{c}}$ \\ ${ }^{1}$ School of Marxism, Dalian University of Technology, Ideological and Political Theory Teaching and Research Faculty,Dalian Jiaotong University, Dalian, Liaoning, China) \\ 2 School of Marxism, Dalian University of Technology, Dalian, Liaoning, China \\ ${ }^{3}$ Ideological and Political Theory Teaching and Research Faculty, Dalian Jiaotong University, Dalian, Liaoning, China) \\ aemail:wenpingdl@sina.com bemail: daiyj@dlut.edu.cn cemail: 294556032 @qq.com \\ ${ }^{*}$ Corresponding author
}

Keywords: Lu Xun's Zawen, College ideological and political work, Value.

\begin{abstract}
Being honored as "the encyclopedia and the epic of modern Chinese social life, Lu Xun's Zawen showed the authors broad view, rich connotation, and great thoughts that endowed the name of Lu Xun the significance across ages and nations. Digging into the deep ideological and political education resources hidden in Lu Xun's Zawen, apprenticed under Lu Xun, this paper is to prompt the ideological and political educators moral and cultural attainment, to use the new media resources to innovate the college ideological and political education work. Furthermore, to carry forward the excellent genetic advantages of Lu Xun's spirit and its eternal enchantment among nations, across time and spaces, to achieve the cultural self-consciousness of our ideological and political education work, to immerse the college students in culture, to realize the cultural self-confidence.
\end{abstract}

\section{Introduction}

The name of Lu Xun is mainly connected with Zawen. Lu Xun started with novels that set up his status in Chinese literature and even Chinese intellectual history, but actually it was his Zawen that contributed the most. ${ }^{[1]}$ Zawen were the main body of Lu Xun's creation. The creation of his Zawen lasted the longest among his whole writing life (started from 1907, ended with his death in 1936) with great results. There are as many as 17 kinds, more 950 Zawen went to publish. Great writers in the world, mostly we just call them litterateur. Lu Xun, however, we may have many comments for him, but the regard of him being a great litterateur and a thinker was without any objection. What did Lu Xun have and others did not? Zawen. Differenced from novels, essays, stories and poets, Zawen can directly state the author's opinion, to implicitly or explicitly release his or her thoughts. "Soul of the massive Chinese' is now reflected in my Zawen." [2]Lu Xun's Zawen have been hailed as "the encyclopedia and the epic of modern Chinese social life", because the great thoughts showed in the broad view and the rich content in his Zawen, which endowed the name of Lu Xun the significance across ages and nations.

\section{Apprenticed under Lu Xun, to improve the ideological and political educator's ideological and moral standards along with their humanity attainment}

At the age of new media that featured by the mobile internet, the worldly tendencies of revolution, innovation, development and diversification, the national conditions of new situations, new problems and new contradictions, the party conditions of facing the four complex ordeals, and the open-minded, diversified and stressed students, are the major questions of reality that college ideological and 
political educators are now facing. With these many complicated, changeable and problematic objective reality rings, educators' competences are challenged enormously. As the propagandist and the performer of Marxism, college ideological and political educators except being politically reliable, should also be capable in theories, in writing, in giving speeches, and in other professions. Otherwise, he or her may become the ideological dwarf and therefore will not truly impress the students, not to mention leading the healthy growth of students. Therefore, the educators should build up the concept of comprehensive and lifelong learning. An excellent ideological and political educator should not only have firm political belief , unequivocal political position and sublime political consciousness, but also the noble sentiment and the right value standard of life. He or she should not only have the solid theoretical foundation and the systematic subject knowledge, but also the excellent eloquence and the ability to command language. He or she should not only have a strong sense of responsibility and mission, but also the ability to work under pressure and the willpower to overcome the sense of loss.

Lu Xun is exemplary. Zhou Haiying said that Lu Xun is a litterateur, but he is a teacher by profession. At today's age of letting Lu Xun "went to the public, to the society, to the enterprises, to the communities, to the world", at such an age of popularizing $\mathrm{Lu} \mathrm{Xun,} \mathrm{the} \mathrm{entry} \mathrm{point} \mathrm{of} \mathrm{us}$ understanding Lu Xun is to begin with "Lu Xun as a teacher". Returned from Japan in June 1909, Lu Xun had his first job at Zhejiang Normal College in his hometown to teach physiology and chemical. 1911, Lu Xun became the headmaster of Shaoxing Normal College. Between the fourteen years from 1912 to 1926, Lu Xun successively served at the Ministry of Education in Nanjing temporary government, and also at the ROC Ministry of Education (the Northern Warlords government). His rivals considered this "official career" as a "smear", which also intentionally or unintentionally avoided by researchers. Secondly, from the angle of historical analysis, whether the Nanjing temporary government or the later ROC, should all be considered as the results of revolution, as the "new" government, the new hope at that time. Moreover, among those fourteen years, his work was mainly in the field of social education, such as the preach of revolution situations, the preparation to build the "central Library", and the preparation of $<$ Culture and Education $>$ Magazine. Most importantly, since the autumn 1920, Lu Xun had has been the part-time lecturer at the Peking University and Beijing Senior Normal College, and then the lecturer (or tutor) at the Beijing Female Senior Normal College, World Language Academy, University of China, Liming Middle School, etc., among which time, Lu Xun had has quit the Ministry of Education three times, but his teaching was never been interrupted. In August 1926, Lu Xun was appointed as professor of liberal arts by the Xiamen University, and then as dean of literature department and director of academic affairs at the Zhongshan University. After his arrival in Shanghai in October 1927, Lu Xun no longer serve as the teacher, but still giving speeches in the universities (including colleges and middle schools). In December 1927, Lu Xun serves as the guest writer at dean of College, Mr. Cai Yuanpei's invitation. All his life, Lu Xun's status as the educator was eminent. Futhermore, to combine his speeches and creation, Lu Xun's position as a ideological educator was remarkable. His ethical conduct of respecting teachers and loving students, erudite and informed cultural deposits, national patriotism, tenacious research attitude, optimistic personality traits, critical and creative way of thinking, along with many other traits, should always be the model for us to learn from. In the heart of President Xi Jinping, Lu Xun was as famous as Li Dazhao, Liang Qichao and other masters of that generation. ${ }^{\text {[3] }}$

\section{Improving media attainment, to use the new media to innovate the college ideological and political education work}

Today's college students of "90 cohorts" are the out and out "digital natives". John Palfrey and Urs Gasse pointed out that "the most lasting change caused by the digital revolution, is not new business modes or new algorithm researches, is rather the generation gap between people who born in the digital age and who born in the non-digital age." The influence of this gap among higher education is increasing. Although teachers from " 80 cohorts" are still thriving, but the heads of specialists are still 
the "digital refugees" and "digital immigrants" before the "80 cohorts". The subversiveness of this fact is that teachers no longer possess the advantage of being the preemptive gainer of knowledge and information. On the contrary, the "digital natives" have the complete advantages of possessing new media technologies, which made the "digital refugees" and the "digital immigrants" become the "cultural counter-breeding" The foundation of respecting teachers is challenged. Teachers without a few specialties have had their authority and confidence swept away by the students' disregard.

The development of new media, not only has great impact on the classroom of college ideological and political education, but also generates a different complicated yet important ideology. The Internet "mirror" of the real society generates the superimposed and focusing effects, will make the online ideologies more and more complicated. The emphasis of ideological and political education should be where the people locate. Therefore, for a very long period, the Internet will be the main battlefield of the different ideologies, and will be the one of four platforms ${ }^{[5]}$ to push the work of ideological theory to innovate and develop. College ideological and political educator needs to improve his or her online new media attainment, should be able to actively occupy and to hold the online position. This is not only a problem of one's ideology, but also a problem of one's willing to action and capabilities.

Lu Xun can be considered as the example of using media to express his voice! "Silenced people, closed thoughts, don't you think the world is not yours to deal with, just like the slaves wearing hats." ${ }^{[6]}$ This is written in the <Chu Shi Ci> for the commence issue of <Yue Duo Daily> in 3 January 1912, to call for people's cry. The Xinhai Revolution succeeded, the shackles of tyranny has been released, but the similar constraints were still there, people do not have their own voices or thoughts, think themselves did not have the rights to ask what's going on in the world, as if they are still slaves wearing hats. "Reign of the republic, children on the shoulders, all be the host, different from the slaves". [6] It's not only the ideological enlightenment to the people, but also the practice, "thus creating this newspaper, all the business partners, come to recommend articles and convey the ideas, let's hope to have a democratic society". ${ }^{[6]}$ From Lu Xun's point of view, the newspaper was not only the result of liberty of the press, but also a significant symbol of whether the public can use the newspaper to express their own voices, which also makes the public different from being the slaves rather than the host of their own country ${ }^{[7]}$. This kind of insight can still enlighten the benighted of today's people. Throughout his whole life, Lu Xun had engaged with at least 123 kinds of newspaper and magazines at home and abroad ${ }^{[8]}$. Lu Xun treated these newspaper and magazines as the window to the world, the resources of his creation, the place to express his thoughts, the battlefield for his fights. It was rare to see people like Lu Xun to publish his creation and translation on the newspaper and magazines home and abroad for decades.

\section{Combing through Lu Xun's Zawen, to enrich the spiritual resources of college ideological and political education}

Lu Xun once said, "Young people who were fed with blighted grain will not grow". ${ }^{[9]}$ He called for that "everybody should do their utmost to import the spiritual food (which refers to the dissemination of the overseas ideologies and the world-famous works that suppressed by the deaf makers at that time), to put surround the young people". Up to this day, does our young people lack of "spiritual food" or not? "College is just like the nursing home, actually many people died in college." The winner of Nobel Prize for literature, Bob Dylan said that in 2016, which impale many educators. Many students have lost their capabilities of deep reading, thinking and finding, and also the capabilities as a quiet listener. They need ideological and spiritual guidance. Lu Xun's impact among college students can be very distinct: on one hand, as the "soul of people", Lu Xun's cultural status in China is unshakable; his countless followers is still coming from the literature department in Chinese colleges. On the other hand, as one of the "three fears" among middle school and college students, the reading of Lu Xun's work is considered as freaky action by the other students (except of literature 
department). In general, because of the excessive reading and requirements of mechanical memorizing of Lu Xun's work in the middle school, many students now take a respectful distance with Lu Xun. Can his Zawen become the contemporary college students' "spiritual granary"?

\section{Summary}

The biggest value presented by Lu Xun's Zawen is to make us think independently, to make us an independent individual. President Xi Jinping considered Lu Xun's work as an important component of Chinese culture, answered the questions of the contemporary value of Lu Xun's work and his heritage policy from a strategically advantageous position [12]. To learn from Lu Xun, to look back and to carry forward the revolution culture and traditions, has the significant importance on firming the cultural confidence and on filling up the spiritual bones of China. Lu Xun and his Zawen are worthy of this appointment!

\section{Acknowledgement}

This research was financially supported by Postgraduate Education Reform Project of Dalian Jiaotong University in 2016, Research and Practice of Research-based Teaching Methods of Principle and Methods of Ideological and Political Education (Grant No. 2016-34), and the Party Building Research Foundation of Dalian Jiaotong University 2017 ,Research on the Ideological and Political Education Value of Lu Xun's Essays (Grant No. DJSZ-2017-B07).

\section{References}

[1] Yuanbao.Gao, Six lectures of Lu Xun, Peking University Press, pp.90, 1977.

[2] Lu Xun, the Complete Works of Lu Xun, vol.5, People's Education Press, pp. 423, 2005.

[3] Xi Jinping, Being a good teacher that satisfied the Party and People - the speech on the seminar with the students and tutors in Beijing Normal University, People's Daily version 2, 2014.

[4] Zhou Xiaohong, The significance of the regurgitation-feeding in the contemporary Chinese youth culture, Youth Studies, vol. 11, pp. 22-26, 1988.

[5] Answering China's issue by China's theory, Analyzing China's developing mode by China's discourse, People's Daily, vol.4, 2015.

[6] Lu Xun, The Complete Works of Lu Xun, People's Literature Publishing House, vol.11, pp. 41-42, 2005.

[7] Wang Chunsen, Xu Lanfang, Lu Xun's View of News and Interest to the Press, Jiangsu University press ,pp. 19, 2012.

[8] Wang Chunsen, Xu Lanfang, Lu Xun's View of News and Interest to the Press, Jiangsu University press, pp. 139, 2012.

[9] Lu Xun, The Complete Works of Lu Xun, vol. 11,People's Literature Publishing House , pp. 259, 2005.

[10]Xiaodu, Du, Jinping Xi Gave A Speech Of Culture To The Student In Macao, People.cn, 2014 http://politics.people.com.cn/n/2014/1221/c1001-26246776.html 